\title{
EXPLORING THE BENEFITS OF SOCIAL MEDIA MARKETING FOR BRANDS AND COMMUNITIES
}

\author{
I-ping Chiang \\ National Taipei University, Taiwan \\ Email: ipchiang@mail.ntpu.edu.tw \\ Ray Wong \\ National Taipei University, Taiwan \\ Email: ntpu.im.iplab@gmail.com \\ Chih-hui Huang \\ National Taipei University, Taiwan \\ Email: ntpu.im.iplab@gmail.com
}

\begin{abstract}
In recent years, social media becomes a new communication channel in marketing. Social media facilitate improved targeting and play a critical role in marketing operations. We collect empirical data that can be used to determine whether social media marketing actually creates brand benefits or increases product sales. We proposed a new model for measuring the effectiveness of social media marketing and explained the benefits created by different brand and user types on social media. By conducting the seemingly unrelated regression estimation (SURE) model, this research collected 1,956 valid samples from the consumers who use the social media marketing. The results show that search goods and experience goods in social media marketing create diverse effective directions in interaction effects. For mobile phone brands other than the iPhone, social benefits were nonsignificant; however, brand benefits for them were significant because of the interplay of benefits.
\end{abstract}

Keywords: Social Media, Social Media Marketing, Brand 


\section{INTRODUCTION}

Over the past decade, social media has become one of the major communication and marketing tools. According to an eMarketer report, the number of brand marketers committing a budget to paid social media advertising has been increasing by $1 \%$ to $2 \%$ yearly ${ }^{1}$. This implies that nearly nine in ten marketers will use social media marketing next year. Social media facilitate improved targeting, and play a critical role in marketing operations. $70 \%$ of customers are using social media to listen and learn about other customers' experiences; $65 \%$ of these customers seek information about brands, products, and services, and $53 \%$ of the customers compliment brands ${ }^{2}$. These facts indicate that customers are no longer information recipients, but are proactively sharing their opinions on products, services, and brands. They express their views about brands ${ }^{3}$; exchange all types of information; promote brand knowledge ${ }^{4}$; and learn about Internet celebrities' experiences through social media ${ }^{5}$.

Although scholars and marketers are aware already of the significance of social media marketing, there are no definitive empirical data that can be used to determine whether social media marketing actually creates brand benefits or increases product sales. Moreover, in the past, most scholars have focused on verifying causality among the joining motivation, participation, and benefits for a single social media channel ${ }^{6,7}$. Discussions about brand and the relationship between user types and benefits in social media marketing research are rare. Therefore, in this study, the benefits of social media marketing were examined by considering seven types of social media users and two types of brands in an attempt to identify the main success factors affecting social media marketing.

\section{LITERATURE REVIEW \\ 2.1 Social media and social media marketing}

Social media is "a group of Internet-based applications that builds on the ideological and technological foundations of Web 2.0, and it allows the creation and exchange of user-generated content" ${ }^{\text {. }}$. According to Hogan and Quan-Haase ${ }^{9}$, social media integrate several computer-mediated 
communication (CMC) features. For example, Facebook, MySpace, and Twitter offer instant messaging and blogging features in addition to their core feature of profile searching ${ }^{9}$. Moreover, social media users can create profiles, search, blog, dynamically follow their connections, and maintain contact with their friends. A standard social media structure does not exist, and social media sites vary in their functions and characteristics ${ }^{10}$.

Social media marketing refers to any form of direct or indirect marketing using social media to build awareness, recognition, recall, and action for a brand, business, product, person, or other entity ${ }^{11,12}$. Unlike personal users, businesses use social media for advertising and marketing ${ }^{13}$. Kaplan and Haenlein ${ }^{14}$ reported that social media offer such advantages as strengthening business-consumer connections, fostering relationships in a timely manner, and establishing long-term relationships at low costs ${ }^{15}$.

\subsection{Brand in social media marketing}

Brand in social media marketing refers to marketers and advertisers creating engaging brand-related content on social media platforms ${ }^{16}$. Mohammadian and Mohammadreza ${ }^{12}$ reported that brand in social media marketing assists businesses in determining customer needs, developing customer relationships, increasing brand awareness, extending promotional marketing reach, and observing market reactions. A specific brand in social media marketing approach involves creating brand fan pages on social media sites ${ }^{16}$. De Vries et al. ${ }^{17}$ theorized that brand fan pages invite users to engage in two-way dialogue, reflect a part of customers' relationship with the brand, broaden the brand-customer relationship, and are a source of user information and benefit ${ }^{18,19}$.

Most scholars have used the search goods and experience goods approach in researching brand in social media ${ }^{20,21}$. Search goods are products and services with features and characteristics that are easily assessable before purchase, such as mobile phones, cameras, and other consumer electronics, whereas those of experience goods, such as food, accommodation, movies, clothes, and group buying products, are not ${ }^{17,22}$. In this study, we selected mobile phones and group-buying brands as the 
subjects because mobile phones represent search goods, and group-buying brands offer two distinct experiences, namely products and services, whose value can be determined only by consuming or experiencing them; moreover, using group-buying websites is itself part of the user experience.

\subsection{User types}

Users exhibit varying participation patterns on social media platforms. Mathwick $^{23}$ classified Internet users as lurkers, socializers, personal connectors, and transactional community members. De Valck et al. ${ }^{24}$ identified six types of virtual community members according to their information activities: informationalists, opportunists, functionalists, hobbyists, conversationalists, and core members. Li and Bernoff $\mathrm{f}^{25}$ distinguished seven types of social media users, who they termed social technographics. 1) Creators, who publish articles, upload homemade videos, and edit individual profile pages. 2) Conversationalists usually post updates and statuses. 3) Critics rate and review products and services and share their evaluations. 4) Collectors subscribe to RSS feeds, label webpages and photos, etc. 5) Joiners maintain profiles and visit social networking sites. 6) Spectators browse for information and read and watch others' statuses, comments, and videos. 7) Inactives, who are uninvolved in social media. Insightxplore ${ }^{26}$ customized Li and Bernoff's research for Internet users in Taiwan by adding sharers and removing inactives. On the basis of the aforementioned studies, this study developed a continuum participation in social media marketing comprising seven types, similar to those of Li and Bernoff $^{25}$ and Insightxplore ${ }^{26}$. Furthermore, we classified the seven types into two categories: only observing other users' conduct (spectators, collectors, and joiners) and users who provide feedback and maintain relationships (sharers, critics, conversationalists, and creators) ${ }^{23,27}$. This study explores the relationship between brands and social media user types to guide brands to optimize their social media marketing.

\subsection{Benefits of social media marketing}

Scholars and marketers have examined social media marketing ${ }^{28,29}$, focusing on consumer interaction and advertising as well as increasing the 
benefits of social media marketing. This research explores the benefits of social media marketing, including brand and social benefits.

\subsection{Brand benefits}

Subgroups and fan pages associated with specific brands are specialized because they are based on a structured set of social relationships among admirers of those brands. Consumers exhibit special behavior toward the brands by interacting with the marketers, administrators, and other consumers. When consumers participate brand events, celebrate the brand's history, or publicly displaying their brand preference ${ }^{19,30}$, it can not only deepen brand impression and familiarity ${ }^{31}$, but enhance future purchase intention. From the aforementioned theories, this study identifies three brand benefits that arise from social media marketing: brand association, brand knowledge, and brand commitment ${ }^{28,29,31,32}$.

First, brand association refers to ideas and evaluations that arise in consumers upon seeing a particular brand ${ }^{31}$. Aaker ${ }^{33}$ considered brandrelated associations as a set of ideas, feelings, and expectations that reflect the characteristics of the brand and product cognition. Schivinski and Dąbrowski ${ }^{28}$ hypothesized that social media consumers having a positive evaluation of the brand through interaction with other consumers may positively influence brand association and even increase the brand's future purchase intentions ${ }^{34,35,36}$. From the relevant literature, this study considers brand association as the most basic brand benefit.

Second, brand knowledge is the consumers' subjective knowledge of a certain brand or its products ${ }^{37}$. Kozinets ${ }^{38}$ indicated that social media users join brand communities anticipating valuable information on the brands and their use. Füller et al. ${ }^{32}$ noted that brand knowledge is more specific than product class knowledge because the former relates to the products of a brand. When consumers believe that brand knowledge on social media is useful and valuable, they are more likely to share such knowledge ${ }^{39}$. Furthermore, scholars have argued that the longer that administrators and marketers interact with consumers on social media, the more brand knowledge the consumers gain (e.g., Matzler et al. ${ }^{40}$ ). 
Last, several researchers have defined brand commitment as the consumers' enduring desire to build and maintain a valued relationship with a brand (e.g., Moorman et al. ${ }^{41}$; Pritchard et al. ${ }^{42}$ ). When consumers are committed to a brand or a company, they are likely to actively cooperate and unlikely to be attracted to the competitors ${ }^{43}$. Kim et al ${ }^{44}$ reported that consumers continually participating in social media activities are exposed to more opportunities to understand the value of a brand, thus enhancing their commitment. In addition, Zhou et al. ${ }^{29}$ proposed that consumers committed to a particular brand on social media are likely to develop brand commitment.

These studies suggest that brands experience different social media benefits according to user type. Therefore, this study proposes the following hypotheses:

H1: Different brands derive different brand benefits.

Hla: Search goods increase its brand benefits.

H1b: Experience goods increase its brand benefits.

H2: Interactions between brands and different user types in social media marketing create different brand benefits.

H2a: Interactions between search goods and high-level user types (creators, conversationalists, critics, and sharers) increase brand benefits.

H2b: Interactions between search goods and low-level user types (spectators, collectors, and joiners) do not increase brand benefits. H2c: Interactions between experience goods and high-level user types (creators, conversationalists, critics, and sharers) do not increase brand benefits.

H2d: Interactions between experience goods and low-level user types (spectators, collectors, and joiners) increase brand benefits.

\subsection{Social benefits}

Academics and marketers have recently explored benefits from social media other than brand benefits. Woisetschläger et al. ${ }^{3}$ recognized that users participating in social media marketing activities by helping other users, 
seeking a response, or developing relationships increase brand trust and consumer satisfaction. Moreover, Jang et al. ${ }^{45}$ stated that users interacting with other users promote positive attitudes and evaluations in online communities, which further enhances its commitment to the community members ${ }^{46}$. Therefore, this research summarizes the factors affecting social benefits: social relationships, social identification, social influence, social satisfaction, and social commitment.

First, social relationships are characterized by repeated and non-faceto-face interactions between social media users ${ }^{47,48}$. According to Zhao et al. ${ }^{49}$, individuals join social media to meet other like-minded individuals, make friends, and find social support. Individuals with similar views and ideas tend to be more interdependent and willing to help others ${ }^{50}$. Sung et al. ${ }^{51}$ theorized that the link between individuals is the core factor influencing the establishment and maintenance of their relationship. Social media users satisfied with their interactions on social media prefer to preserve the relationships, which prompts social commitment ${ }^{52}$.

Second, users with similar qualities and outlooks easily develop a sense of belonging and social identification ${ }^{53,54}$. Yeh and Choi ${ }^{39}$ suggested that consumers undergo a self-categorization process and select one or more brands with which they identify on social media; because of the shared feelings and values, community members feel interconnected and separate themselves from nonmembers ${ }^{55}$. Zhou et al. ${ }^{29}$ conjectured that members demonstrate social identification by sharing brand experiences, engaging with the brand's content, and drawing similar functional utility from social media.

Third, social influence comprises two aspects: individuals' perception of their influence on social media and the influence that social media exert over individuals ${ }^{56,57}$. Social influence is defined as an individual being affected by a group idea because of peer pressure or the anticipation of acquiring rational or emotional recognition from peers. The higher the degree of group cohesion on social media, the greater the influence on individuals' decision-making ${ }^{4}$. Social influence also includes the influence of individuals such as opinion leaders. Because such individuals derive self- 
satisfaction from exerting their influence, they continually participate in community activities ${ }^{57}$.

Forth, social satisfaction is the overall attitude toward or evaluation of performance and is based on an individual's experiences ${ }^{58}$. Casaló et al. ${ }^{59}$ reported that satisfaction does not arise from learning, sharing, advocating, or commenting behaviors but from a global evaluation of the historical relationship between members, which reflects the past, current, and future performance of social media ${ }^{3,59}$. De Valck et al. ${ }^{60}$ described satisfaction as a long-term and cumulative evaluation of social media and proposed four elements for measuring satisfaction: member-to-member, member-toorganizer, and organizer-to-community interactions, and the social media platform contextualizing these interactions.

Last, social commitment is the enduring desire to maintain a long-term relationship with a group; it is essential and valuable because of the similar characteristics or closeness shared by the members ${ }^{61}$. According to Jang et al. ${ }^{45}$, social commitment represents the attitudinal and psychological factors of social media members willing to maintain the relationship. Raïes and Gavard-Perret ${ }^{22}$ stated that continued and enthusiastic participation in social media activities enhances a member's commitment. When members interact, positive emotional and social links are developed over time, which generates more security in the relationship ${ }^{62}$. Furthermore, Mathwick et al. ${ }^{63}$ reported that when social media users consider providing information and continually helping fellow members as their obligation and responsibility, the desire to maintain social relationships represents social commitment.

The preceding discussion shows that in social media marketing, different brands derive different social benefits depending on user type. Thus, this study proposes the following hypotheses:

H3: Different brands derive different social benefits.

H3a: Search goods increase its social benefits.

H3b: Experience goods increase its social benefits.

H4: Interactions between brands and different user types in social media marketing create different social benefits. 
H4a: Interactions between search goods and high-level user types (creators, conversationalists, critics, and sharers) do not increase social benefits.

H4b: Interactions between search goods and low-level user types (spectators, collectors, and joiners) increase social benefits.

H4c: Interactions between experience goods and high-level user types (creators, conversationalists, critics, and sharers) increase social benefits.

H4d: Interactions between experience goods and low-level user types (spectators, collectors, and joiners) do not increase social benefits.

\section{MEASUREMENT \\ 3.1 Questionnaire design}

According to literature reviews, we measured the effectiveness of social media marketing and the benefits created by different brands and user types on social media. In this study, the online questionnaire started with the measures of the benefits toward brands and communities. All questionnaire were measured on a six-point Likert scale ranging from "strongly disagree"(1) to "strongly agree"(6).

Before administering the formal social media marketing questionnaire, we asked two questions to ensure the reliability of the respondents. First, the respondents were asked "Do you habitually use the following social media?" Respondents who selected Facebook were randomly assigned to a brand's fan page questionnaire. Second, the respondents were asked "Will you follow the brand's official fan page on Facebook?" If the respondent's answer conflicted their pretest answers or if they selected not to follow the assigned fan page, they were not administered the questionnaire. Last, the respondents conducted user types, brand benefits, and social benefits questionnaire.

In this study, we developed seven types of social media user (spectators, collectors, joiners, sharers, critics, conversationalists, and creators). User types measures were adapted from Mathwick ${ }^{23}$, Li and Bernoff $^{25}$, and Muntinga et al. ${ }^{27}$. This study used Facebook as its main 
subject of research and selected two leading consumer categories in Taiwan, namely mobile brands (HTC, iPhone, Samsung, and Sony) as search goods and group buying brands (17Life, GOMAJI, and Groupon) as experience goods, to determine the influence of various brands' activities on social media marketing. Based on the literature reviews, we included two social media marketing benefit factors (brand benefits: brand association, brand knowledge, and brand commitment; social benefits: social relationships, social identification, social influence, social satisfaction, and social commitment) to examine seven types of social media users and two types of brands. However, brand association measures were adapted from Schivinski and Dąbrowski's scale ${ }^{28}$. We assessed three items, such as 'I can quickly recall the symbol or logo of [brand].' The 5-item attitude toward the brand knowledge measure (e.g., In comparison with others, I know a lot about [brand].) was adapted from Füller et al. ${ }^{32}$ and Sung et al. ${ }^{51}$. Brand commitment measures were derviced from Zhou et al. ${ }^{29}$ and assessed using three items. Besides, social relationships measures were adapted from Dholakia et al. ${ }^{18}$ and Sung et al. ${ }^{51}$. Both social identification and social satisfaction scale items were derived from Woisetschläger et al. ${ }^{3}$. Social commitment measures proceed from Zhou et al. ${ }^{29}$ and Mathwick et al. ${ }^{63}$ (see APPENDIX). Lastly, we also collected the demographic of gender and age.

\subsection{Seemingly Unrelated Regression Estimation Model}

The seemingly unrelated regression estimation (SURE) model was developed from Zellner ${ }^{64}$. The concept behind SURE model is to fit a number of regression equations at once and use the covariance in the errors of each regression equation to know the other. However, when a model has two or more regression equations, the error term between each regression equation is likely to be correlate. The SURE model accounts for these correlations in the error terms and is also appropriate when unmeasured variables may produce a relationship between the dependent variables after controlling for the independent variables.

In this research, we used a seemingly unrelated regression estimation (SURE) model to test the relationship between brand and user type in social 
media marketing. Since some brands share some attributes, correlation to answers are likely. To account for correlation between the errors of the regression equations, we adopted the SURE model. Therefore, the control variables in this study are the social media user types. Sony and Groupon form the baseline group, which ensures that the derived benefits are directly attributable to (a) the main effect of brands (model 1) or (b) the interactive effect of brand and user types (model 2).

\section{RESULT AND ANALYSIS}

Our study cooperated with InsightXplorer. The InsightXplorer survey and the Cyberpanel system were implemented to collect samples ${ }^{65}$. To ensure the sampling conforms to real Internet users in Taiwan, the sampling ratio is for Internet users from the Department of Statistics, Ministry of Interior. In this research, 1,956 effective samples were collected. The sampling gender and age are shown in Table 1.

Table 1. Demographic data

\begin{tabular}{ccc}
\hline Gender & Count & Percentage \\
\hline Male & 906 & $46.3 \%$ \\
Female & 1050 & $53.7 \%$ \\
Total & 1956 & $100.0 \%$ \\
\hline Age & Count & Percentage \\
\hline Under 19 years old & 32 & $1.6 \%$ \\
20-24 years old & 248 & $12.7 \%$ \\
25-29 years old & 308 & $15.7 \%$ \\
30-34 years old & 404 & $20.7 \%$ \\
35-39 years old & 379 & $19.4 \%$ \\
40-44 years old & 231 & $11.8 \%$ \\
45-49 years old & 153 & $7.8 \%$ \\
Over 50 years old & 201 & $10.3 \%$ \\
Total & 1956 & $100.0 \%$ \\
\hline
\end{tabular}


Table 2. Brand Benefits in Mobile Brands

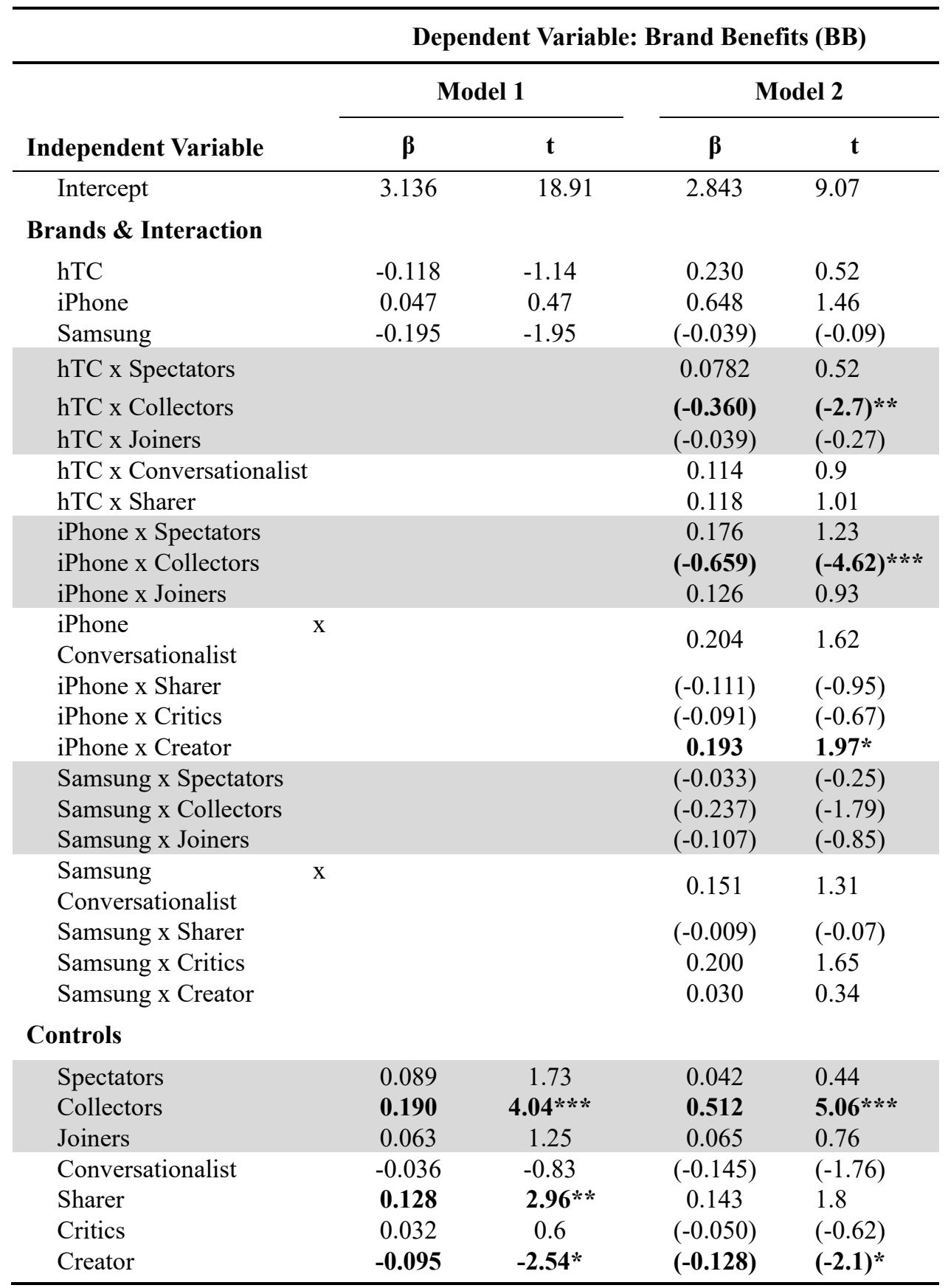

Sony is control group. R-Square in model 1 and model 2 are 0.314 and 0.370 .

$* * * \rho<.001 ; * * \rho<.01 ; * \rho<.05$ 
Table 3. Brand Benefits in Group-buying Brands

\begin{tabular}{|c|c|c|c|c|}
\hline \multirow[b]{3}{*}{ Independent Variable } & \multicolumn{4}{|c|}{ Dependent Variable : Brand Benefits (BB) } \\
\hline & \multicolumn{2}{|c|}{ Model 1} & \multicolumn{2}{|c|}{ Model 2} \\
\hline & $\boldsymbol{\beta}$ & $\mathbf{t}$ & $\boldsymbol{\beta}$ & $\mathbf{t}$ \\
\hline Intercept & 2.654 & 15.6 & 3.032 & 11.31 \\
\hline \multicolumn{5}{|l|}{ Brands \& Interaction } \\
\hline 17Life & 0.022 & 0.23 & -0.466 & -1.17 \\
\hline GOMAJI & -0.047 & -0.46 & -0.600 & -1.55 \\
\hline 17Life x Spectators & & & 0.044 & 0.33 \\
\hline 17Life x Collectors & & & 0.178 & 1.42 \\
\hline 17Life x Joiners & & & -0.145 & -0.96 \\
\hline 17Life $\mathrm{x}$ Conversationalist & & & 0.002 & 0.02 \\
\hline 17Life x Sharer & & & 0.051 & 0.46 \\
\hline 17Life x Critics & & & 0.075 & 0.65 \\
\hline 17Life x Creator & & & -0.080 & -0.77 \\
\hline GOMAJI x Spectators & & & 0.057 & 0.45 \\
\hline GOMAJI x Collectors & & & 0.069 & 0.58 \\
\hline GOMAJI x Joiners & & & 0.018 & 0.13 \\
\hline GOMAJI x Conversationalist & & & 0.117 & 1.02 \\
\hline GOMAJI x Sharer & & & -0.124 & -1.28 \\
\hline GOMAJI x Critics & & & 0.028 & 0.22 \\
\hline GOMAJI x Creator & & & -0.032 & -0.3 \\
\hline \multicolumn{5}{|l|}{ Controls } \\
\hline Spectators & 0.078 & 1.52 & 0.039 & 0.42 \\
\hline Collectors & 0.003 & 0.06 & -0.086 & -1.07 \\
\hline Joiners & 0.207 & $3.68 * * *$ & 0.211 & 2.41* \\
\hline Conversationalist & -0.042 & -0.9 & -0.075 & -0.99 \\
\hline Sharer & -0.039 & -0.97 & 0.003 & 0.05 \\
\hline Critics & 0.187 & $3.9 * * *$ & 0.159 & $2.1^{*}$ \\
\hline Creator & 0.032 & 0.77 & 0.087 & 1.2 \\
\hline
\end{tabular}

Groupon is control group. R-Square in model 1 and model 2 are 0.339 and 0.332 .

$* * * \rho<.001 ; * * \rho<.01 ; * \rho<.05$

Table 2 and Table 3 show the SURE result about brand benefit (BB) in mobile and group-buying brands. In terms of main effect, both kinds of brand showed not significantly differences from the control group ( $\mathrm{P}>$ 0.05 ), which means the main effect were not verified, so $H 1$ were not verified.

When taking user type in social media in to account, the results of 
interactions were similar to our hypotheses. For $H 2$, the interaction of iPhone $\times$ creators was greater than Sony, showing the high-level user types will increase search goods' brand benefits, so $H 2 a$ was verified ; HTC $\times$ collectors and iPhone $\times$ collectors were found to be significantly less than Sony, it means the interactions between search goods and low-level user types will not increase its brand benefits, hence $H 2 b$ was verified. In the group-buying brands, interactions outcome was not significantly different regardless of any level of user types ( $\mathrm{P}>0.05)$, hence $H 2 c$ was verified and $H 2 d$ was not verified. Consequently, there showed opposite situation among search goods and experience goods in brands benefits.

The result from text of social benefit (SB) showed in Table 4 and Table 5. When not considered the user types in social media marketing, both kinds of brand showed not significantly differences from the control group ( $\mathrm{P}>$ 0.05). However, when bring into the user types, iPhone was significant creating social benefits, it means some of search goods indeed increase its social benefits. Therefore, it was partially support $H 3$ because $H 3 a$ was verified and $H 3 a$ was not verified.

In $\mathrm{H} 4$, we argued that social benefits are influenced by the interaction between brands and user types in social media. The Table 4 showed that none of indicators was significantly differences from the Sony in interaction effect $(\mathrm{P}<0.05)$, and it showed that the interactions between search goods and user types will not increase its social benefits. Therefore, $H 4 a$ was verified and $H 4 b$ was not verified. For group-buying brands, the results we showed in Table 5 displaying that high-level user types in experience goods were not increase its social benefits, hence $H 4 c$ was not verified. In the lowlevel user types, the social benefits were created by 17Life $\times$ joiners and GOMAJI $\times$ joiners were significantly less than control group, but 17 Life $\times$ collectors developed positive social benefits comparing with Groupon. It is partially support $H 4 d$. 
Table 4. Social Benefits in Mobile Brands

\begin{tabular}{|c|c|c|c|c|}
\hline \multirow[b]{3}{*}{ Independent Variable } & \multicolumn{4}{|c|}{ Dependent Variable: Social Benefits (SB) } \\
\hline & \multicolumn{2}{|c|}{ Model 1} & \multicolumn{2}{|c|}{ Model 2} \\
\hline & $\boldsymbol{\beta}$ & $\mathbf{t}$ & $\boldsymbol{\beta}$ & $\mathbf{t}$ \\
\hline Intercept & 2.140 & 12.45 & 1.807 & 5.33 \\
\hline \multicolumn{5}{|l|}{ Brands \& Interaction } \\
\hline $\begin{array}{l}\text { hTC } \\
\text { iPhone } \\
\text { Samsung }\end{array}$ & $\begin{array}{c}0.090 \\
0.119 \\
-0.057\end{array}$ & $\begin{array}{c}0.84 \\
1.14 \\
-0.55\end{array}$ & $\begin{array}{l}0.523 \\
\mathbf{0 . 9 7 8} \\
0.091\end{array}$ & $\begin{array}{l}1.09 \\
\mathbf{2 . 0 4} * \\
0.21\end{array}$ \\
\hline $\begin{array}{l}\text { hTC x Spectators } \\
\text { hTC x Collectors } \\
\text { hTC x Joiners }\end{array}$ & & & $\begin{array}{c}(-0.085) \\
(-0.115) \\
0.026\end{array}$ & $\begin{array}{l}(-0.52) \\
(-0.79) \\
0.16\end{array}$ \\
\hline $\begin{array}{l}\text { hTC x Conversationalist } \\
\text { hTC x Sharer }\end{array}$ & & & $\begin{array}{c}(-0.034) \\
0.110\end{array}$ & $\begin{array}{l}(-0.25) \\
0.87\end{array}$ \\
\hline $\begin{array}{l}\text { iPhone x Spectators } \\
\text { iPhone x Collectors } \\
\text { iPhone x Joiners }\end{array}$ & & & $\begin{array}{c}-0.116 \\
(-0.124) \\
0.047\end{array}$ & $\begin{array}{l}(-0.75) \\
(-0.81) \\
0.3\end{array}$ \\
\hline $\begin{array}{l}\text { iPhone x Conversationalist } \\
\text { iPhone x Sharer } \\
\text { iPhone x Critics } \\
\text { iPhone x Creator }\end{array}$ & & & $\begin{array}{c}0.071 \\
(-0.120) \\
(-0.082) \\
0.115\end{array}$ & $\begin{array}{l}0.52 \\
(-0.95) \\
(-0.55) \\
1.09\end{array}$ \\
\hline $\begin{array}{l}\text { Samsung x Spectators } \\
\text { Samsung x Collectors } \\
\text { Samsung x Joiners }\end{array}$ & & & $\begin{array}{l}(-0.049) \\
(-0.022) \\
(-0.116)\end{array}$ & $\begin{array}{l}(-0.35) \\
(-0.15) \\
(-0.85)\end{array}$ \\
\hline $\begin{array}{l}\text { Samsung x Conversationalist } \\
\text { Samsung x Sharer } \\
\text { Samsung x Critics } \\
\text { Samsung x Creator }\end{array}$ & & & $\begin{array}{c}0.115 \\
(-0.121) \\
0.250 \\
(-0.079)\end{array}$ & $\begin{array}{l}0.92 \\
(-0.95) \\
1.9 \\
(-0.83)\end{array}$ \\
\hline \multicolumn{5}{|l|}{ Controls } \\
\hline Spectators & -0.011 & -0.21 & 0.058 & 0.56 \\
\hline Collectors & 0.153 & $3.14 * *$ & 0.213 & 1.95 \\
\hline Joiners & 0.039 & 0.75 & 0.063 & 0.68 \\
\hline Conversationalist & -0.071 & -1.57 & $(-0.112)$ & $(-1.26)$ \\
\hline Sharer & 0.142 & $3.17 * *$ & 0.174 & $2.04 *$ \\
\hline Critics & 0.159 & $2.9 * *$ & 0.076 & 0.86 \\
\hline Creator & 0.109 & $2.8 * *$ & 0.128 & 1.94 \\
\hline
\end{tabular}

Sony is control group. R-Square in model 1 and model 2 both are 0.473 .

$* * * \rho<.001 ; * * \rho<.01 ; * \rho<.05$ 
Table 5. Social Benefits in Group-buying Brands

\begin{tabular}{|c|c|c|c|c|}
\hline \multirow[b]{3}{*}{ Independent Variable } & \multicolumn{4}{|c|}{ Dependent Variable: Social Benefits (SB) } \\
\hline & \multicolumn{2}{|c|}{ Model 1} & \multicolumn{2}{|c|}{ Model 2} \\
\hline & $\boldsymbol{\beta}$ & $\mathbf{t}$ & $\boldsymbol{\beta}$ & $\mathbf{t}$ \\
\hline Intercept & 1.968 & 11.48 & 2.180 & 8.38 \\
\hline \multicolumn{5}{|l|}{ Brands \& Interaction } \\
\hline 17Life & 0.129 & 1.33 & -0.464 & -1.2 \\
\hline GOMAJI & -0.085 & -0.83 & -0.049 & -0.13 \\
\hline 17Life $\mathrm{x}$ Spectators & & & 0.117 & 0.92 \\
\hline 17Life x Collectors & & & 0.431 & $3.56 * * *$ \\
\hline 17Life x Joiners & & & -0.327 & $-2.24 *$ \\
\hline 17Life x Conversationalist & & & 0.001 & 0.01 \\
\hline 17Life x Sharer & & & 0.096 & 0.88 \\
\hline 17Life x Critics & & & -0.152 & -1.35 \\
\hline 17Life x Creator & & & -0.040 & -0.4 \\
\hline GOMAJI x Spectators & & & 0.000 & 0 \\
\hline GOMAJI x Collectors & & & 0.166 & 1.43 \\
\hline GOMAJI x Joiners & & & -0.267 & $-2 *$ \\
\hline GOMAJI x Conversationalist & & & 0.135 & 1.21 \\
\hline GOMAJI x Sharer & & & -0.030 & -0.32 \\
\hline GOMAJI x Critics & & & -0.063 & -0.5 \\
\hline GOMAJI x Creator & & & 0.057 & 0.55 \\
\hline \multicolumn{5}{|l|}{ Controls } \\
\hline Spectators & 0.032 & 0.62 & -0.035 & -0.39 \\
\hline Collectors & 0.000 & 0.01 & -0.163 & $-2.1 *$ \\
\hline Joiners & 0.140 & $2.48 *$ & 0.286 & $3.36 * * *$ \\
\hline Conversationalist & -0.023 & -0.49 & -0.045 & -0.61 \\
\hline Sharer & -0.032 & -0.8 & -0.033 & -0.53 \\
\hline Critics & 0.293 & $\begin{array}{c}\mathbf{6 . 0 8 *} \\
* *\end{array}$ & 0.344 & $4.69 * * *$ \\
\hline Creator & 0.113 & $\begin{array}{c}2.68 * \\
*\end{array}$ & 0.126 & 1.79 \\
\hline
\end{tabular}

Groupon is control group. R-Square model 1 and model 2 are 0.486 and 0.519 .

$* * * \rho<.001 ; * * \rho<.01 ; * \rho<.05$ 


\section{CONCLUSION AND SUGGESTIONS}

This study summarized the brand and user types in social media marketing from relevant literature. A survey was conducted using quota designed according to Internet user demographics, and reliability and validity analyses were performed to ensure the validity of the selected samples. The SURE model was used to verify the effect of social media marketing on brand and community. From the results, conclusions on the influence of social media marketing were drawn for three aspects; search goods and experience goods presented nearly converse results.

In model 1, no significant differences were seen in social mediaderived benefits for mobile or group-buying brands when only brands were considered in social media marketing. Because most brands undertake similar marketing activities on social media, they cannot generate different benefits than their competitors do. However, when considering user type (model 2), the iPhone exhibited an outstanding performance in social benefits as the main effect, because marketers offered more features for their fans on the iPhone fan page than the marketers for the other brands did. In addition to receiving and replying to official information, all users could post to the iPhone fan page. Therefore, to increase social benefits, we recommend that social media marketers derestrict posting limits, particularly for search goods.

Because mobile phone products are primarily associated with the brand image, brands and user types may have dissimilar brand interests and preferences, resulting in different brand benefits. For example, creators, who help marketers increase brand benefits in their community, are the best representatives of the iPhone fan page. Collectors were substantially less influential on the iPhone and HTC fan pages than they were on the Sony fan page. Because collectors usually label or save articles for themselves, they interact less with others; such participations may be ineffective for the iPhone and HTC pages. For search goods, high-level users may have high brand interest and preferences and generate more brand benefits. Hence, for search goods, marketers should focus on the dynamic and reactive highlevel user types on social media, because they affect the brand perceptions 
of all community members. In addition, marketers should consider working with creators, which not only enhances the users' brand satisfaction and commitment but also inspire creative and unique brand ideas.

According to the results of model 2, group-buying brands derive significant difference in social benefits but not brand benefits, possibly because the social media sites of group-buying brands contain numerous members willing to buy the same item at discounted prices from a retailer. Compared with the brand influence, the relationship and cohesion within the community are more critical. These findings reveal that the joiner members are substantially less active on the 17Life and GOMAJI fan pages than they are on the Groupon fan page, suggesting that joiners are crucial users for Groupon and help Groupon create higher social benefits. Collectors in the 17Life community highly influence social benefits and are majority contributors to the community's satisfaction and commitment; they are effective indicators segment market from competitors. According to these results, collectors are essential and are considered high-degree participators in experience goods on social media, particularly for groupbuying brands. Hence, we recommend that marketers focus on collectors by reviewing what information, words, and curations they prefer, which can enhance product sales.

One feature of the SURE model is that the dependent variables interact with each other, meaning that brand and social benefits were mutually influenced in this study. The results show that search goods and experience goods in social media marketing create diverse effective directions in interaction effects. For mobile phone brands other than the iPhone, social benefits were nonsignificant; however, brand benefits for them were significant because of the interplay of benefits. In other words, the impact of mobile phone brands in social media marketing is directly driven by brand benefits and indirectly driven by social benefits in interaction effects. Conversely, in group-buying brands, social benefits are directly generated by the interactions and brand benefits are indirectly affected by social benefits.

This study proposed a new model for measuring the effectiveness of 
social media marketing and explained the benefits created by different brand and user types on social media. Unlike previous studies, the current study employed the SURE analysis to compare the findings of the main and interaction effects and considered the interactive effects in discussing the relationship between brand benefits and social benefits. In addition, we used two brand types as examples and concluded that, for brand marketers, merely joining, building official fan pages, and sharing information is insufficient; they must focus on the roles played by different user types and brand characteristics. The outcomes clarify the contributions of brand and user types in brand and social value; therefore, we recommend that scholars and marketers focus on user types in social media marketing and develop distinct social media marketing strategies according to the user types and brands.

On the basis of the presented discussions, this study provides brand marketers and Internet marketing researchers with academic references for brand positioning and decision-making in social media marketing. However, because only Taiwanese social media users were included in the study, the results may be applicable only to Taiwan's unique online networks. Therefore, future studies can focus on comprehensive perspectives by clarifying regional and cultural influences. Furthermore, this study used Facebook as its main research subject. Future research can examine other social media platforms, such as Twitter, Google+, and Instagram, and consider various brand types. Moreover, future studies can incorporate other explanatory variables to increase contributions. 


\section{REFERENCES}

[1] eMarketer, The Year of Social?, 2013. Retrieved on September 8, 2017. Retrieved from https://www.emarketer.com/Article/Year-ofSocial $/ 1010386$

[2] Social Media Examiner, Social Media Marketing Industry Report, 2013. Retrieved on September 8, 2017 from

https://www.socialmediaexaminer.com/social-media-marketingindustry-report-2012/

[3] D. M. Woisetschläger, V. Hartleb, and M. Blut, How to make brand communities work: Antecedents and consequences of consumer participation. Journal of Relationship Marketing, 7(3), 237-256, 2008. https://doi.org/10.1080/15332660802409605

[4] J. Koh, Y. G. Kim, and Y. G. Kim, Sense of virtual community: A conceptual framework and empirical validation. International Journal of Electronic Commerce, 8(2), 75-94, 2003.

https://doi.org/10.1080/10864415.2003.11044295

[5] L. V. Casaló, C. Flavián, and M. Guinalíu, Promoting consumer's participation in virtual brand communities: A new paradigm in branding strategy. Journal of Marketing Communications, 14(1), 1936, 2008. https://doi.org/10.1080/13527260701535236

[6] Algesheimer, R., Dholakia, U. M., and Herrmann, A. (2005). The social influence of brand community: Evidence from European car clubs. Journal of Marketing, 69(3), 19-34. Retrieved January 7, 2020, from www.jstor.org/stable/30162054

[7] J. Van Doorn, K. N. Lemon, V. Mittal, S. Nass, D. Pick, P. Pirner, and P. C. Verhoef, Customer engagement behavior: theoretical foundations and research directions. Journal of Service Research, 13(3), 253-266, 2010. https://doi.org/10.1177/1094670510375599

[8] S. Vinerean, I. Cetina, L. Dumitrescu, and M. Tichindelean, The effects of social media marketing on online consumer behavior. International Journal of Business and Management, 8(14), 66, 2013. https://doi.org/10.5539/ijbm.v8n14p66

[9] B. Hogan, and A. Quan-Haase, Persistence and change in social media. Bulletin of Science, Technology and Society, 30(5), 309-315, 2010. https://doi.org/10.1177/0270467610380012

[10] D. G. Taylor, J. E. Lewin, and D. Strutton, Friends, fans, and followers: do ads work on social networks? Journal of Advertising Research, 51(1), 258-275, 2011. https://doi.org/10.2501/JAR-51-1-258-275

[11] S. Gunelius, 30-minute social media marketing: Step-by-step techniques to spread the word about your business. McGraw-Hill, 2011.

[12] M. Mohammadian, and M. Mohammadreza, Identify the success factors of social media (Marketing Perspective). International 
Business and Management, 4(2), 58-66, 2012. https://doi.org/10.3968/j.ibm.1923842820120402.1120

[13] A. J. Kim, and E. Ko, Do social media marketing activities enhance customer equity? An empirical study of luxury fashion brand. Journal of Business Research, 65(10), 1480-1486, 2012. https://doi.org/10.1016/j.jbusres.2011.10.014

[14] A. M. Kaplan, and M. Haenlein, Users of the world, unite! The challenges and opportunities of Social Media. Business Horizons, 53(1), 59-68, 2010. https://doi.org/10.1016/j.bushor.2009.09.003

[15] W. C. Martin, 2009. Investigating the antecedents and consequences of perceived connectedness to brand users: Brand communities versus brand collectivities (Doctoral dissertation). Mississippi State University, Mississippi, MS. Retrieved on September 8, 2017, from http://search.proquest.com.sw.library.ntpu.edu.tw:81/docview/30494 1309/fulltextPDF/1418990F8CB483498E6/1?accountid=8008

[16] S. Holzner, Facebook marketing: Leverage social media to grow your business. Indianapolis, IN: Que Publishing, 2009.

[17] L. De Vries, S. Gensler, and P. S. Leeflang, Popularity of brand posts on brand fan pages: An investigation of the effects of social media marketing. Journal of interactive marketing, 26(2), 83-91, 2012. https://doi.org/10.1016/j.intmar.2012.01.003

[18] U. M. Dholakia, R. P. Bagozzi, and L. K. Pearo, A social influence model of consumer participation in network-and small-group-based virtual communities. International Journal of Research in Marketing, 21(3), 241-263, 2004. https://doi.org/10.1016/j.ijresmar.2003.12.004

[19] J. H. McAlexander, J. W. Schouten, and H. F. Koenig, Building brand community. Journal of Marketing, 66(1), 38-54, 2002. https://doi.org/10.1509/jmkg.66.1.38.18451

[20] M. T. Copeland, Relation of consumers' buying habits to marketing methods. Harvard Business Review, 1(3), 282-289, 1923.

[21] P. Kotler, Marketing management. USA: Prentice Hall, 2003.

[22] K. Raïes, and M. L. Gavard-Perret, Brand loyalty intention among members of a virtual brand community: The dual role of commitment. Recherche et Applications en Marketing (English Edition), 26(3), 2341, 2011. https://doi.org/10.1177/205157071102600302

[23] C. Mathwick, Understanding the online consumer: A typology of online relational norms and behavior. Journal of Interactive Marketing, 16(1), 40-55, 2002. https://doi.org/10.1002/dir.10003

[24] K. De Valck, G. H. Van Bruggen, and B. Wierenga, Virtual communities: A marketing perspective. Decision Support Systems, 47(3), 185-203, 2009. https://doi.org/10.1016/j.dss.2009.02.008

[25] C. Li, and J. Bernoff, Groundswell: Winning in a world transformed 
by social technologies. Boston:Harvard Business Press, 2008.

[26] Insightxplore, 2012. 2012 Online Community White Paper. Retrieved on September 8, 2017, from https://zh.scribd.com/document/117223697/2012\%E5\%B9\%B4\%E7 \%B6\%B2\%E8\%B7\%AF\%E7\%A4\%BE\%E7\%BE\%A4\%E7\%99\%B D\%E7\%9A\%AE\%E6\%9B\%B8

[27] D. G. Muntinga, M. Moorman, and E. G. Smit, Introducing COBRAs: Exploring motivations for brand-related social media use. International Journal of Advertising, 30(1), 13-46, 2011. https://doi.org/10.2501/IJA-30-1-013-046

[28] B. Schivinski, D. Dąbrowski, 2015. In Faculty of Management and Economics. The Impact of Brand Communication on Brand Equity Dimensions and Brand Purchase Intention Through Facebook. Gdansk University of Technology, Gdańsk, Poland. Retrieved on September 8 , 2017 , from ftp://ftp.zie.pg.gda.pl/RePEc/gdk/wpaper/WP_GUTFME_A_4_Schiv inskiDabrowski_revised2.pdf

[29] Z. Zhou, Q. Zhang, C. Su, and N. Zhou, How do brand communities generate brand relationships? Intermediate mechanisms. Journal of Business Research, 65(7), 890-895, 2012. https://doi.org/10.1016/j.jbusres.2011.06.034

[30] A. M. Muniz Jr, and T. C. O'guinn, Brand community. Journal of Consumer Research, 27(4), 412-432, 2001. https://doi.org/10.1086/319618

[31] K. L. Keller, Conceptualizing, measuring, and managing customerbased brand equity. Journal of Marketing, 57(1), 1-22, 1993. https://doi.org/10.1177/002224299305700101

[32] J. Füller, K. Matzler, and M. Hoppe, Brand community members as a source of innovation. Journal of Product Innovation Management, 25(6), 608-619, 2008. https://doi.org/10.1111/j.1540-5885.2008.00325.x

[33] D. A. Aaker, Measuring brand equity across products and markets. California management review, 38(3), 102-120,1996. https://doi.org/10.2307/41165845

[34] A. Bhattacherjee, Individual trust in online firms: Scale development and initial test. Journal of Management Information Systems, 19(1), 211-241, 2002. https://doi.org/10.1080/07421222.2002.11045715

[35] R. G. Netemeyer, B. Krishnan, C. Pullig, G. Wang, M. Yagci, D. Dean, J. Ricks, and F. Wirth, Developing and validating measures of facets of customer-based brand equity. Journal of Business Research, 57(2), 209-224, 2004.

https://doi.org/10.1016/s0148-2963(01)00303-4 
[36] P. A. Pavlou, Consumer acceptance of electronic commerce: Integrating trust and risk with the technology acceptance model. International journal of electronic commerce, 7(3), 101-134, 2003. https://doi.org/10.1080/10864415.2003.11044275

[37] K. L. Keller, Strategic brand management: Building, measuring, and managing brand equity, second edition, upper saddle river, $\mathrm{NJ}$ : Prentice Hall, 2003.

[38] R. V. Kozinets, The field behind the screen: using netnography for marketing research in online communities. Journal of Marketing Research, 39(1), 61-72, 2002. https://doi.org/10.1509/jmkr.39.1.61.18935

[39] Y. H. Yeh, and S. M. Choi, MINI-lovers, maxi-mouths: An investigation of antecedents to eWOM intention among brand community members. Journal of Marketing Communications, 17(3), 145-162, 2011. https://doi.org/10.1080/13527260903351119

[40] K. Matzler, E. Pichler, and A. Hemetsberger, 2007. Who is spreading the word? The influence of extraversion and openness on consumer passion and evangelism. American Marketing Association Winter Educators' Conference, San Diego. Retrieved on September 8, 2017, from https://www.researchgate.net/publication/234023910_Who_is_spread ing the_word_The_influence_of_extraversion_and_openness_on_co nsumer_passion_and_evangelism

[41] C. Moorman, G. Zaltman, and R. Deshpande, relationships between providers and users of market research: The dynamics of trust within and between organizations. Journal of marketing research, 29(3), 314, 1992. https://doi.org/10.2307/3172742

[42] M. P. Pritchard, M. E. Havitz, and D. R. Howard, Analyzing the commitment-loyalty link in service contexts. Journal of the academy of marketing science, 27(3), 333-348, 1999. https://doi.org/10.1177/0092070399273004

[43] W. M. Hur, K. H. Ahn, and M. Kim, Building brand loyalty through managing brand community commitment. Management Decision, 49(7), 1194-1213, 2011. https://doi.org/10.1108/00251741111151217

[44] J. W. Kim, J. Choi, W. Qualls, and K. Han, It takes a marketplace community to raise brand commitment: The role of online communities. Journal of Marketing Management, 24(3-4), 409-431, 2008.https://doi.org/10.1362/026725708x306167

[45] H. Jang, L. Olfman, I. Ko, J. Koh, and K. Kim, The influence of online brand community characteristics on community commitment and brand loyalty. International Journal of Electronic Commerce, 12(3), 57-80, 2008.https://doi.org/10.2753/jec1086-4415120304 
[46] I. Kang, K. C. Lee, S. Lee, and J. Choi, Investigation of online community voluntary behavior using cognitive map. Computers in Human Behavior, 23(1), 111-126, 2007.

https://doi.org/10.1016/j.chb.2004.03.039

[47] D. Godes, D. Mayzlin, Y. Chen, S. Das, C. Dellarocas, B. Pfeiffer, B. Libai, S. Sen, M. Shi, and P. Verlegh, The firm's management of social interactions. Marketing Letters, 16(3-4), 415-428, 2005.

https://doi.org/10.1007/s11002-005-5902-4

[48] R. Hofstetter, S. K. Shriver, H. Nair, and K. Miller, 2010. Social ties and user generated content: Evidence from an online social network. SSRN eLibrary, 59(6), 1425-1443. Retrieved on September 8, 2017, from

http://www.hec.unil.ch/hec/hec_en_bref/evenements/Hofstetter_pape r_online_marketing.pdf

[49] L. Zhao, Y. Lu, B. Wang, P. Y. Chau, and L. Zhang, Cultivating the sense of belonging and motivating user participation in virtual communities: A social capital perspective. International Journal of Information Management, 32(6), 574-588, 2012. https://doi.org/10.1016/j.ijinfomgt.2012.02.006

[50] Y. Lu, L. Zhao, and B. Wang, From virtual community members to C2C e-commerce buyers: Trust in virtual communities and its effect on consumers' purchase intention. Electronic Commerce Research and Applications, 9(4), 346-360, 2010. https://doi.org/10.1016/j.elerap.2009.07.003

[51] Y. Sung, Y. Kim, O. Kwon, and J. Moon, An explorative study of Korean consumer participation in virtual brand communities in social network sites. Journal of Global Marketing, 23(5), 430-445, 2010. https://doi.org/10.1080/08911762.2010.521115

[52] M. Givertz, and C. Segrin, Explaining personal and constraint commitment in close relationships: The role of satisfaction, conflict responses, and relational bond. Journal of Social and Personal Relationships, 22(6), 757-775, 2005. https://doi.org/10.1177/0265407505058674

[53] H. J. Schau, and A. M. Muniz Jr, Brand communities and personal identities: Negotiations in cyberspace. Advances in Consumer Research, 29(1), 344-349, 2002.

[54] N. Ellemers, P. Kortekaas, and J.W. Ouwerkerk, Self-categorization, commitment to the group and group self-esteem as related but distinct aspects of social identity. European of Social Psychology, 29(2-3), 371-389, 1999.

https://doi.org/10.1002/(sici)1099-0992(199903/05)29:2/3<371::aidejsp932>3.0.co;2-u

[55] M. A. Hogg, and D. I. Terry, Social identity and self-categorization 
processes in organizational contexts. Academy of Management Review, 25(1), 121-140, 2000.

https://doi.org/10.5465/amr.2000.2791606

[56] D. Abfalter, M. E. Zaglia, and J. Mueller, Sense of virtual community: A follow up on its measurement. Computers in Human Behavior, 28(2), 400-404, 2012. https://doi.org/10.1016/j.chb.2011.10.010

[57] P. L. Obst, L. Zinkiewicz, and S. G. Smith, Sense of community in science fiction fandom, Part 1: Understanding sense of community in an international community of interest. Journal of Community Psychology, 30(1), 87-103, 2001. https://doi.org/10.1002/jcop.1052

[58] Anderson, E. W., \& Fornell, C. (n.d.). A Customer Satisfaction Research Prospectus. Service Quality: New Directions in Theory and Practice, 241-268.

[59] L. V. Casaló, C. Flavián, and M. Guinalíu, Relationship quality, community promotion and brand loyalty in virtual communities: Evidence from free software communities. International Journal of Information Management, 30(4), 357-367, 2010. https://doi.org/10.1016/j.ijinfomgt.2010.01.004

[60] K. De Valck, F. Langerak, P. C. Verhoef, and P. W. Verlegh, Satisfaction with virtual communities of interest: effect on members' visit frequency. British Journal of Management, 18(3), 241-256, 2007. https://doi.org/10.1111/j.1467-8551.2006.00499.x

[61] J. P. Meyer, N. J. Allen, and C. A. Smith, Commitment to organizations and occupations: Extension and test of a three-component conceptualization. Journal of Applied Psychology, 78(4), 538-551, 1993. https://doi.org/10.1037/0021-9010.78.4.538

[62] B. B.Stern, Advertising intimacy: relationship marketing and the services consumer. Journal of Advertising, 26(4), 7-19, 1997. https://doi.org/10.1080/00913367.1997.10673532

[63] C. Mathwick, C. Wiertz, and K. De Ruyter, Social capital production in a virtual P3 community. Journal of Consumer Research, 34(6), 832849, 2008. https://doi.org/10.1086/523291

[64] A. Zellner, An efficient method of estimating seemingly unrelated regressions and tests for aggregation bias. Journal of the American statistical Association, 57(298), 348-368, 1962. https://doi.org/10.1080/01621459.1962.10480664

[65] InsightXplorer, What is IX Survey. Retrieved on September 8, 2017, from http://www.ixresearch.com/products/ 


\section{APPENDIX}

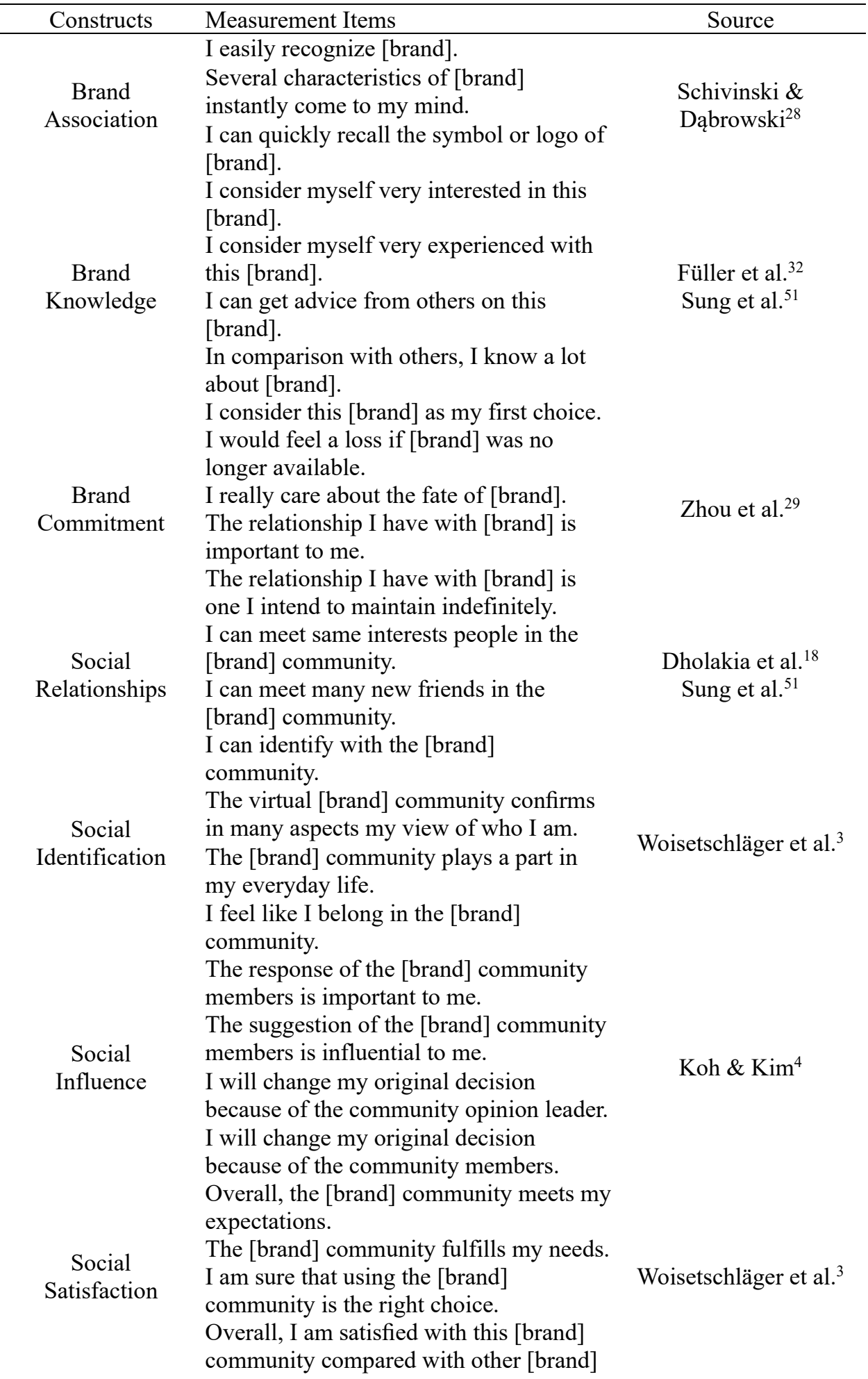


Social

Commitment communities.

The relationship I have with [brand]

community is important to me.

The relationship I have with [brand] community is one I intend to maintain indefinitely.

I feel like "part of the family" in the [brand] community.

In comparison with other community, I receive support from members more easily in the [brand] community.
Zhou et al. ${ }^{29}$

Mathwick et al. ${ }^{63}$ 
